\title{
Formation of technical potential of agriculture in the conditions of the digital economy
}

\author{
Asiya Kamilevna Subaeva ${ }^{1}$, Leysan Mingalievna Mavlieva ${ }^{1}$, Natalia Rodionovna Alexandrova ${ }^{2}$ \\ ${ }^{1}$ Kazan State Agrarian University, Kazan, Russia \\ ${ }^{2}$ Ulyanovsk Agricultural University named afterP. A. Stolypin, Ulyanovsk, Russia
}

\begin{abstract}
The article discusses the role of digitalization of the technical potential of the agricultural industry, describes the factors that have a significant impact on the digitalization of technical potential. The material systematizes data on the formation and development of the technical potential of agriculture. The paper shows that the digital ecosystem is based on the functioning of a complex of electronic platforms, which combine the full range of data on the dynamics of development and the potential of each area of the agro-industrial complex. The elements of production potential, as a historically developing category, have been identified. It was revealed that for the transformation of agriculture, it is necessary to change the development of the reproduction process, which depends, first, on the volume of funds invested, while investments should be aimed at replenishing and updating fixed and circulating assets, the introduction of progressive digital technologies. The basis for the digital transformation of agriculture should be the improvement of the technical characteristics of labor instruments and the equipment of workers, which provides the bulk of the growth in production efficiency.
\end{abstract}

\section{Introduction}

The ability of enterprises to solve large-scale production and technological problems, to increase the output of products or services, to improve its structure is possible only with an increase in technical and technological potential through an increase in the volume of fixed and circulating assets used and the use of more advanced technologies. In the modern world, the word "potential" is used to denote the means, reserves, and sources available, which are used to achieve goals, to solve the problems of the state in any area. The technological potential is a component of the production potential of the enterprise.

Kleiner G. B notes that the technological potential of a particular enterprise consists of the following components: technological preparation of production; equipment; technological processes [1].

In the 20th century, the concepts of resource and production potential appear in economic science, corresponding to the general theoretical concept of productive forces [2]. The elements of production potential in many sources [3] include resources that are associated with the functioning and development of enterprises: organizational and managerial resource, human resource, material and technical resource, information resource.

The production potential of the enterprise is revealed only with the combination and joint development of all its constituent elements. In this regard, the production potential of enterprises is a complex organizational and economic system. Fedorenko N. P. defines this system as "a system of social production, that is, as a set of productive forces and production relations", and in a narrow sense - as a "system of production relations corresponding to a given specific mode of production" [3].

\section{Methods}

The depth and strength of connections between the elements of the economy are a defining feature for identifying subsystems that can be considered as relatively independent local systems within systems of a higher order (hierarchical principle of construction). Therefore, the technical potential should also be considered as an independent subsystem of the material and technical base.

Technical potential must be viewed as a historically evolving category. Even K. Marx argued that scientific and technical discoveries and inventions are caused by production needs, which cannot be satisfied with the old means [4].

K. Marx pointed out that the constant cause of the development of technology must be sought in the contradiction between the past (materialized) and living (direct) labor. The labor of substance-flax in the instruments of labor, which are the products of past labor. So, in the process of labor, a person changes, and living labor moves forward from the materialized, which makes

Corresponding author: marat181@rambler.ru 
it necessary to "pull up" the past labor, developing technology [5]. This is precisely the basis of the economic content of the technical potential.

Technology is constantly developing, which is associated with productive relations, which can slow down or accelerate the development of productive forces and technology. The development of technology is expedient when the labor spent on its manufacture is less labor that replaces its application [6].

According to the "Strategy for the Development of the Information Society of the Russian Federation for 20172030", approved in Russia on May 9, 2017: "The digital economy is an economic activity in which digital data, processing large volumes and the use of results are the key production factors. Analysis, in comparison with traditional forms of management, can significantly increase the efficiency of various types of production, technologies, equipment, storage, sale, delivery of goods and services."

In the state program "Digital Economy of the Russian Federation" approved on July 28, 2017, by the Government of the Russian Federation, the digital economy is defined as an economic activity, the key production factor in which is data in digital form, which contributes to the formation of an information space, taking into account the needs of citizens and society in obtaining - qualitative and reliable information, the development of the information infrastructure of the Russian Federation, the creation and application of Russian information and telecommunication technologies, as well as the formation of a new technological basis for the social and economic sphere.

In relation to the agricultural industry in the departmental project "Digital Agriculture", the concept of the same name is considered as agriculture based on modern methods of producing agricultural products and food using digital technologies (Internet of Things, robotics, artificial intelligence, big data analysis, ecommerce, etc.), providing an increase in labor productivity and a decrease in production costs.

A feature of the digitalization of the technical base of agriculture is the conduct of economic activities with the storage of data in electronic form and the constant processing of information in large volumes, which makes it possible to obtain accurate and objective analytical reports that form the basis for optimizing the processes of agrarian production. The Internet of Things, blockchain, and artificial intelligence have become the components of an economy operating with the involvement of digital means. [7]

The efficiency of agricultural production and the level of its intensity are inextricably linked with the organizational and economic mechanism of reproduction and rational use of the material and technical base of the agro-industrial complex.

At the same time, the material and technical equipment of agricultural enterprises and the methods of reproduction of the material and technical base in the digital economy depend on the financial condition, size of the enterprise, organizational and legal form, and other criteria that affect the receipt of loans and state support funds. The economic efficiency of farmers is greatly influenced by production management, which determines the introduction of modern digital technologies, which ensures a significant increase in crop yields, livestock productivity, labor productivity, and a decrease in production costs.

In the conditions of the digital economy, the level of technical equipment, quality, and reliability of products, which depend on the high-quality state of technology and its effective use, come to the fore. Improving the technical characteristics of the means of labor and equipping workers with them provide the main part of the growth in production efficiency.

The development of the reproduction process depends, first, on the number of funds invested, while investments should be aimed at replenishing and updating fixed and circulating assets and introducing progressive digital technologies. In this regard, agricultural enterprises need to ensure the reproduction process in the required amount of investment resources. Reproduction is associated not only with the renewal of factors of production but also in the corresponding forms of economic, production relations is classified into simple, extended, and narrowed.

The formation of technical potential in modern conditions is presented in the author's form in the following diagram (Fig. 1).

The introduction of digital technologies in agriculture can help producers of agricultural products by increasing labor productivity, reducing costs and increasing production volumes to repay leases for equipment ahead of schedule, within the framework of a preliminary agreement with the lessor. 


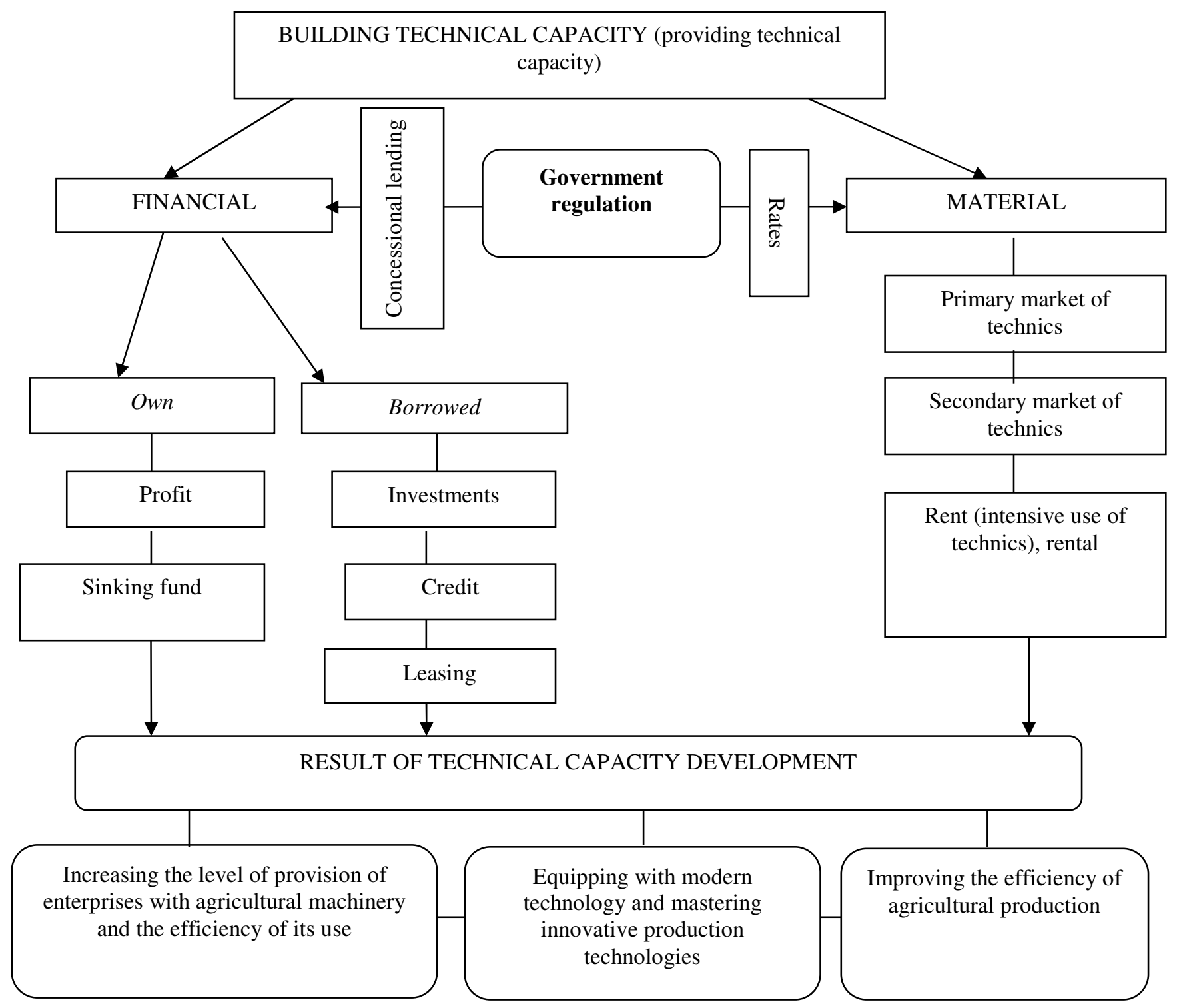

Fig. 1. Formation and development of the technical potential of agriculture

\section{Results}

The factors that have a significant impact on the digitalization of the technical potential of agriculture are as follows: peculiarities of rural formations (size of the territory, size, and structure of the population, economic potential, production capabilities of the region, state of engineering infrastructure, level of development of the social sphere); Labor Organization; used management technologies; the degree of automation of the control system; professional personal qualities of agricultural workers; the level of interest of the personnel in the results of the activity of the farm [8].

The efficiency of digitalization of the agricultural industry, and in particular the crop production industry, can be increased by creating an electronic platform for the sale of agricultural products, on which transactions will be concluded not only with intermediaries but also with end customers. This will reduce the margin of intermediaries and provide incentives for producers. Elements of the digital economy can be used to monitor land, crops, optimize settlements between producers and buyers, and rationalize the investment and credit system, and social insurance. Digitalization involves the active use of marketing techniques, opposition to monopoly, creation of conditions for electronic interaction between all participants in the economy. [8]

From studies of the concept of "digital economy", the authors have identified its constituent elements:

- digital infrastructure (hardware, interface, software, telecommunications, network coverage, etc.);

- digital information base (digitized data, electronic map of fields, climate control, satellite data, etc.);

- Personnel with digital competencies (training of new generation personnel, reducing the role of a person in economic processes); 
- Internet of Things (robotization, synchronization of information and communication tools in real-time via the Internet of Things, etc.);

- electronic sales market (the genesis of markets in the virtual space and reducing the role of material form, electronic exchanges, control "from farm to table", food net, etc.);

- decision support system (analytics, cloud computing, artificial intelligence, big data, etc.).

The introduction of digital technology into the technical potential with various intelligent IT applications that process them in real-time contributes to the rapid decision-making by farmers as a result of analyzing multiple factors and justifying actions for the technical re-equipment of production.

The study of innovative achievements in the form of sensors and self-driving equipment (drones) collecting data in the agricultural industry, connected platform management systems and applications bring agricultural production to a new level, which in turn allowed us to determine the vectors for the development of the digital economy (Table 1).

According to leading scientists of the Ural Agar University Voronin, B. A., Loretts, O. G., Mitin, A. N., Chupina, I. P., Voronina, Y. V, the most common classes of IT solutions in agriculture are systems enterprise management (ERP), accounting systems, electronic document management systems, satellite communications and navigation solutions, vehicle security and control systems, personnel management systems, assets and business processes, business intelligence solutions, CRM systems. Moreover, ERP systems integrate other classes of IT solutions. The main technological trend in agriculture is precision farming, which is the most economically and environmentally efficient use of each hectare of land, as well as seeds, fertilizers, fuels and lubricants, and plant protection products. As a result, there is a reduction in the cost of producing one centner of products and an increase in productivity [9].

Table 1. Vectors of development of digital agriculture

\begin{tabular}{|c|c|c|}
\hline Directions & Characteristic & Applied and Recommended Digital Technologies \\
\hline Management & $\begin{array}{l}\text { Improving the organization of interaction of } \\
\text { agricultural enterprises with authorities, support } \\
\text { institutions, suppliers, buyers }\end{array}$ & $\begin{array}{l}\text { Automatic control systems Decision support systems } \\
\text { (including scenario modeling) } \\
5 \mathrm{G} \text { data networks } \\
\text { Remote accounting and control system }\end{array}$ \\
\hline Marketing & $\begin{array}{l}\text { Increasing the efficiency of research processes in } \\
\text { the field of marketing, advertising and product } \\
\text { promotion. New models of process management. } \\
\text { New methods of interacting with customers }\end{array}$ & $\begin{array}{l}\text { Decision support systems (including scenario } \\
\text { modeling) } \\
\text { Virtual and augmented reality technologies } \\
\text { Remote accounting and control system } \\
\end{array}$ \\
\hline Economy & $\begin{array}{l}\text { Increasing the ability to access and occupy certain } \\
\text { niches. Possibility of global coverage of markets. } \\
\text { Automation of research of data on customer } \\
\text { needs. Improving the efficiency of services, } \\
\text { excluding intermediaries. }\end{array}$ & $\begin{array}{l}\text { Distributed ledger technologies (blockchain) } \\
\text { Artificial Intelligence } \\
\text { Big Data Sharing Technologies }\end{array}$ \\
\hline $\begin{array}{l}\text { Economic and } \\
\text { digital security }\end{array}$ & $\begin{array}{l}\text { The movement of real assets is accompanied by } \\
\text { digital media and channels in their various forms, } \\
\text { which changes the essence of industrial and } \\
\text { economic relations. }\end{array}$ & $\begin{array}{l}\text { Artificial Intelligence } \\
\text { Remote accounting and control system } \\
\text { Automatic control systems Decision support systems } \\
\text { (including scenario modeling) }\end{array}$ \\
\hline Agroengineering & $\begin{array}{l}\text { Technologies for computer and remote } \\
\text { diagnostics of machines. Prospects for the use of } \\
\text { 3D technologies in the design of repair and } \\
\text { technological equipment, robotic complexes, } \\
\text { "smart" warehouses for spare parts and oil } \\
\text { products. }\end{array}$ & $\begin{array}{l}\text { Machines and equipment with unmanned, semi- } \\
\text { unmanned modes } \\
\text { Unmanned vehicles (UAVs, satellites, unmanned } \\
\text { ground vehicles, agricultural robots) } \\
\text { Technique with semi-automatic, controlled movement } \\
\text { across the field (for example, parallel driving), spatial } \\
\text { control systems for the performance of operations } \\
\text { Sensors, sensors, scanners, controllers, testers, } \\
\text { samplers for monitoring soil, plants (installed on } \\
\text { agricultural machinery or independent) }\end{array}$ \\
\hline Finance & $\begin{array}{l}\text { Digital technologies increase the efficiency of } \\
\text { enterprise value chain management. }\end{array}$ & $\begin{array}{l}\text { Remote accounting and control system } \\
\text { Cloud computing, global computing } \\
\text { Artificial Intelligence }\end{array}$ \\
\hline Integration & $\begin{array}{l}\text { The process of network interaction through the } \\
\text { process of creating a unified information space } \\
\text { that provides the possibility of prompt and timely } \\
\text { exchange of information between automated } \\
\text { systems of public administration, management of } \\
\text { an agro-industrial enterprise, industrial } \\
\text { production, training, sales of products and } \\
\text { provision of services. }\end{array}$ & $\begin{array}{l}\text { Data analysis including big data } \\
\text { Big Data Sharing Technologies } \\
\text { GPS navigation and positioning } \\
\text { Earth remote sensing }\end{array}$ \\
\hline Plant growing & $\begin{array}{l}\text { The process of preserving soil fertility through the } \\
\text { system of precision farming and soil management. }\end{array}$ & $\begin{array}{l}\text { GIS technologies (electronic maps, field mapping by } \\
\text { NDVI-type indicators, by relief, agro-ecological } \\
\text { parameters, field history book, etc.) } \\
\text { GPS navigation and positioning } \\
\text { Remote sensing of the earth. }\end{array}$ \\
\hline
\end{tabular}




\begin{tabular}{|l|l|l|}
\hline & & $\begin{array}{l}\text { Forecasting systems yield modeling } \\
\text { Unified fieldwork assignment card }\end{array}$ \\
\hline Livestock & $\begin{array}{l}\text { Traceability of the origin and quality of livestock } \\
\text { products, creation of obstacles to the spread of } \\
\text { epidemics and illegal trade in animal products. }\end{array}$ & $\begin{array}{l}\text { Wireless sensor networks } \\
\text { 5G data networks } \\
\text { Remote accounting and control system } \\
\text { Virtual, augmented reality technologies } \\
\text { Big Data Sharing Technologies } \\
\text { Artificial Intelligence } \\
\text { Remote accounting and control system } \\
\end{array}$ \\
& $\begin{array}{l}\text { Forecasting systems productivity modeling } \\
\text { Remote diagnosis of diseases }\end{array}$ \\
\hline Processing & $\begin{array}{l}\text { Foodnet - production and sale of nutrients and } \\
\text { final types of food products, as well as related IT } \\
\text { solutions, for example, providing services for } \\
\text { logistics and selection of individual food. }\end{array}$ & $\begin{array}{l}\text { Remote accounting and control system } \\
\text { Virtual, augmented reality technologies } \\
\text { Big Data Sharing Technologies }\end{array}$ \\
\hline
\end{tabular}

Source: compiled by the authors

The identified vectors of development of digital agriculture allow a more differentiated approach to the study and regulation of industrial relations necessary for the effective implementation of digital technologies, substantiating the need for investments, assessing the formation of a value chain, balancing the structure of investments, and assets associated with the introduction of digital technologies.

\section{Implications}

The digital market for agricultural machinery is a market for technical resources, in which transactions for the sale and purchase of goods are carried out using computer networks and specialized software. The functioning of such a platform is provided by a digital platform, that is, a set of software and technical products, a set of rules for the operation of the market infrastructure. Notable examples of digital platforms in operation are Uber, Airbnb. For the agro-industrial complex, it is advisable to create a separate platform for each area of activity with the introduction of a network of sub-platforms. For example, concerning the crop production of the agroindustrial complex, one of the sub-platforms can be grain production, and the grain sub-platform can be divided into several more sites - wheat, barley, corn, etc. Agricultural producers, that is, sellers, and buyers enterprises of the processing industry, livestock farms, and feed mills, become participants in the sub platforms [10].

\section{Conclusions}

In the Russian agro-industrial complex, the digital transformation of the technical unit of the agro-industrial complex is at the initial stage. Legally approved programs for the informatization of the industry and the economy are currently not deeply developed and are more aimed at automating already established processes, but they do not propose measures for a radical transformation of the economy. The digitalization of agriculture contributes to a significant reduction in production costs and an increase in the financial availability of food, ensures the rational use of the potential of natural resources.

\section{References}

1. G.B. Kleiner, What mesoeconomics does Russia need? Regional perspective in the light of systemic economic theory, Bulletin of the Financial University, 4 (2014)

2. N.A. Sereda, The need to regulate the agricultural machinery market in the context of restricting food imports, Agro-industrial complex: Economics, management, 11 (2014)

3. L.S. Sosnenko, Analysis of the economic potential of an operating enterprise (Publishing House of Economic Literature, Moscow, 2003) 208 p.

4. V.N. Kuzmin, Agricultural machinery production and the global financial and economic crisis, Bulletin of MSAU, 5 (2014)

5. K. Marx, F. Engels, Works. Vol. 1-39. 2d edition. (Moscow Political Literature Publishing House, 1955-1974)

6. A.N. Semin, M. M. Kislitskiy, I.Y. Agnaeva, V.Y. Vorona, Domestic experience of the formation of the local level of the rural economy by means of digital technologies, STAGE, 6 (2018)

7. O.V. Lazko, S.V. Semchenkova, O.L. Lukasheva, Strategic guidelines for managing digital transformation processes in the agro-industrial complex, Moscow Economic Journal, 4 (2018)

8. S.B. Ognivtsev, The concept of a digital platform for the agro-industrial complex, MSH, 2 (2018)

9. B.A. Voronin, O.G. Loretts, A.N. Mitin, I.P. Chupina, Y.V. Voronina, On the issue of digitalization of Russian agriculture (review of information materials), Agrarian Bulletin of the Urals, 2(181) (2019)

10. A.A. Nurullin, A. K. Subaeva, N.R. Aleksandrova, Performance as the main factor of expanded reproduction, IIOAB Journal, 10(S2) (2019) 